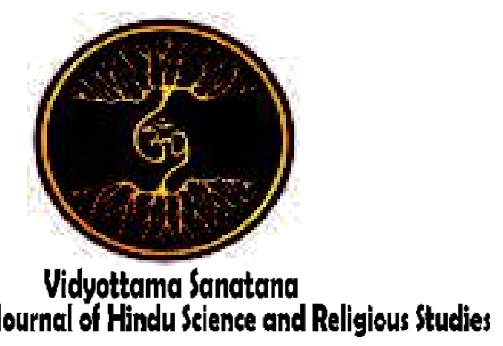

International Journal of Hindu Science and Religious Studies

Vol. 5 No. 2 October 2021

\title{
THE EFFECTIVENESS OF CHARACTER VALUE INTERNALIZATION THROUGH NGUSABHA SAMBAH TOWARDS BALI AGA CULTURE RESILIENCE TENGANAN PEGRINGSINGAN VILLAGE, MANGGIS DISCRICT, KARANGASEM REGENCY
}

\author{
By: \\ Putu Ersa Rahayu Dewi ${ }^{1}$, I Nyoman Suadnyana ${ }^{2}$, Luh Putu Widya Fitriani ${ }^{3}$ \\ ${ }^{1,2,3}$ STAHN Mpu Kuturan Singaraja \\ E-mail: 1 ersarahayu14@gmail.com , ${ }^{2}$ nsuadnyana98@gmail.com, \\ 3widyafitriani14@gmail.com
}

Received: August 30, 2021

Accepted: August 31, 2021

Published: October 31, 2021

\begin{abstract}
Every human individual is always in the process of forming his character, because a character is formed starting from the family, school, and environment. Formally, the formation of human character is formed consciously and systematically in developing self-potential. Tenganan Pegringsingan Traditional Village has a religious tradition which is considered as a place for internalizing character values which is devoted as a form of cultural resilience in the Tenganan Pegringsingan Traditional Village, which is held annually and every three years for muran which is marked with sasih kapat twice in one year which is right on sasih kalima according to the calendar system of the Tenganan Pegringsingan Traditional Village is called Ngusaba Sambah. The results of this scientific paper using a qualitative research with an ethnographic approach.
\end{abstract}

Keywords: tradition, character, ngusabha sambah, culture 


\section{INTRODUCTION}

Every human is always in the process of forming his character, where a character is formed starting from the family, school and environment. Formally the formation of human character is formed consciously and systematically in developing selfpotential which is called education carried out in school institutions. The process or method of instilling normative values that determine the desired behavior for a system that educates in accordance with the guidelines towards the formation of a dignified and characterized national personality, through the process of internalizing education based on the principles of religious, social and cultural norms. Internalization is a part in or within, about the appreciation of a teaching or value, so that belief and awareness of the truth about values is embodied in attitudes and behavior. Setting into thoughts or personalities, actions, values, benchmarks, ideas or practices from others and becoming part of oneself (Kartono, 2000: 236).

Bali is known to have a variety of uniqueness and very high cultural values in the practice of religion which is dominated by various forms of yadnya ceremonies. Balinese culture today is the result of a culture that undergoes a continuous process in the form of preservation, screening, processing, adaptation and acceptance as well as the development of various cultural systems, ranging from indigenous culture, Hindu culture, to national and global culture which cannot be separated from the rules of culture. Such units are strengthened by the unity of customs and sacred religious ceremonies (Koentjaraningrat, 1999: 297). In addition to a strong culture, of course there are elements of religious ceremonies that animate every culture found in Bali, one of which is in the old village of Bali Aga, namely the Tenganan Pegringsingan traditional village.

There are many ceremonies or religious rituals based on customs in the
Tenganan Pegringsingan Traditional Village which are very interesting to talk about and look at more closely, which is considered a place for internalizing character values which is devoted as a form of cultural resilience in the Tenganan Pegringsingan Traditional Village. Rows of rituals or yadnya ceremonies are presented every sasih (month system on the Balinese calendar). The concept of carrying out the ceremony for each sasih by the people of the Tenganan Pegringsingan Traditional Village is called the concept of "nemu galang" which is described as a history of cycles, the rotating circle where there is no end and always rotates.

One of the Dewa Yadnya ceremonies in the Tenganan Pegringsingan Traditional Village is Ngusabha Sambah which is held annually and every three years for muran which is marked by sasih kapat twice a year or is often said by the people of Tenganan Pegringsingan Traditional Village with the name kapat sep and one year having 13 months and exactly on sasih kalima according to the calendar system of the Tenganan Pegringsingan Traditional Village. When Ngusabha Sambah, which is believed to be the peak of human life, begins to interact with many parties. The biggest offering ceremony and carried out in the longest period of time, namely a full month. This is because in adolescence to adulthood, human life also lasts relatively longer than childhood or old age. Ngusabha Sambah presents many relevant values in character life for cultural defense, based on this, this study aims to determine how effective the internalization of character values produced through Ngusabha Sambah is against the resilience of Bali Aga culture in the land of Tenganan Pegringsingan.

\section{METHOD}

Research on the effectiveness of internalizing the value of the Ngusabha Sambah character on cultural resilience in the Tenganan Pegringsingan Traditional Village, Manggis District, Karangasem 
Regency uses a qualitative research with an ethnographic approach, with the data collection methods used are; 1) observation, 2) literature, 3) interview, 4) documentation.

\section{RESULTS AND DISCUSSION a. Ngusabha Sambah}

The Ngusabha Sambah ceremony in the Tenganan Pegringsingan Traditional Village is held on the sasih kalima. The Ngusabha Sambah ceremony is carried out as a tribute to the Supreme God, namely the god of Indra because the Tenganan Pegringsingan Traditional Village is mostly filled with rice fields and farms, thus the god of Indra as the god of fertility and the god of rain is believed to be able to give the grace of rain when the rice fields and farms experience drought to reach fertility in Tenganan Village which is able to support all human beings who live in the Tenganan Pegringsingan Traditional Village. According to Ketut Sudiastika (interviewed on June $7^{\text {th }} 2021$ )

The series of Ngusabha Sambah ceremonies begins with the patipanten ceremony. The patipanten ceremony is held on the $1^{\text {st }}$ of the Sasih Kalima. Patipanten is a monthly handover meeting activity. When the Patipanten ceremony will be held, the krama desa before sunset Saye (verbal informant) ngatag while carrying bungan base. After the members of the krama desa present based on the complete structure, then continued the next ritual in a row for 1 full month including, Wilangan Pamuja, Preparation of Mamiyut, Mamiyut and Usabha Sambangan, Pengejukan Ombo, Penampahan Ombo, Nyacah Bakatan, Pebani Sambah, Purnama Sambah, Mulan Saat, Mulan Daha, Penampahan Muran, Muran Desa, Malingmalingan, Mabuang Kala, Kare-Kare Desa, Penampahan Uran, Muran Teruna, Melasti, Makare-Kare Petemu Kelod, Kare-kare Petemu
Kaja, Kare-kare Petemu Tengah, Nguling, Tilem, Patipanten, and Nyajah.

The culmination of this Ngusabha Sambah ceremony is the perang pandan or makare ceremony held on Hud pang 12 of the sasih kalima. Makare begins to be marked with a gamelan selonding on the patemu and the performers prepare to follow the procession. Makare is only intended for men. During this makare, the youngsters look like the brave knights who were at war and were witnessed by the daha above the patemu. The makare process is actually a dance that displays dexterity between the performers, by pressing the pandan thorns over the bodies of each of the performer. There is no revenge or anger in this makare activity because all this is carried out based on ancestral heritage and ngayah. After the makare or perang pandan is completed, the youths who participated in the makare activity were given the opportunity to participate in the jambal magibungan at the place where the perang pandan was held accompanied by mutual help between the youths while giving special medicine so that the wounds affected by the pandan thorns dry immediately. After it was completed, the youths were allowed to get up from the magibung place and continued with daha maanyunan activities starting from the patemu kaja to the patemu kelod by using the saput kebaya kuning.

\section{b. Effectiveness of Value Internalization of Ngusabha Sambah}

The success of a goal is measured by the concept of effectiveness. Related to the definition of effectiveness, there are differences of opinion among those who use it, both among academics and practitioners. The descriptive measurement of the effectiveness of internalization in the Ngusabha Sambah Ceremony in the Tenganan Pegringsingan Traditional Village was carried out through three stages 
of implementation. In the first stage of transformation in the internalization process, educators do it through verbal communication. This value transformation process is only the transfer of knowledge from educators to students. The value given by the educator is still in the cognitive domain of the learner and this knowledge may be lost if one's memory is not strong.

Students who are intended in the realm of value transformation, namely Krama Desa and teruna-daha Traditional village of Tenganan Pegringsingan. The ancestors of the traditional village of Tenganan Pegringsingan have always understood the importance of an education for the next generation, which at first, before they knew formal education, Krama Desa and teruna-daha the Tenganan Pegringsingan Traditional Village, a place has been provided to gain knowledge about ethics, morals and so on, through various traditions and cultures, one of which is Ngusabha Sambah which incidentally is a form of protection for the character development of its generation. Knowledge of the traditions and culture that belongs to it as a Bali Aga village, as a whole is given materially in the educational process aimed at Krama Desa and teruna-daha.

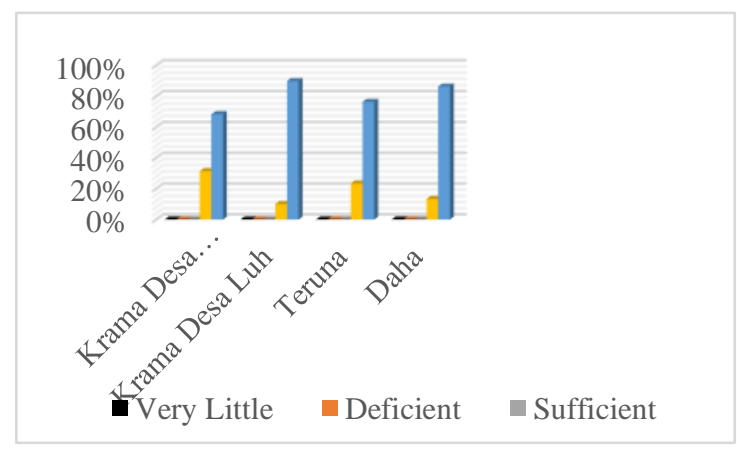

Based on the results of the diagram above can be obtained, the transformation of the values of human life is not engineered or forced but flows naturally. The transformation of the values of human life moves evolutionarily which can definitely change the thought patterns and attitudes from one generation to the next one, the importance of a transformation of values done by the previous ancestors to the teruna-daha and then enter the krama desa organization that is nothing else to remain maintain the traditions it has.

The second stage of the value transaction stage is the second process. In the process stage of the effectiveness of internalizing character values to krama desa and teruna-daha in entering ethical values in maintaining a tradition they have. The actualization of character values in internalization leads to ethics and morals. At this stage, value education is carried out through two-way communication that occurs between educators and students that are reciprocal, hence an interaction process occurs. With value transactions, the educator can have an influence on his students through examples of values that he has run. On the other hand, krama desa and teruna-daha will determine the value that suits them. Value transactions can be formulated as a trait contained in something that places it in a valuable and honorable position, namely that this trait makes something sought and loved, whether loved by one person or a group of people, these traits want to be nurtured to the students. It is because the truth is, if it is not the terunadaha as the next generation, who else will continue to keep the traditions of the Tenganan Pegringsingan Traditional village. A motivation in building the character of the teruna-daha, in two-way communication with the stages of the process. Internalization of character value transactions, as a form of understanding and meaning of character education given through religious aspects or based on religion, will form a good combination without any conflicting or contradictory values.

The third stage of the Trans-stage of internalization effectiveness is a much deeper stage than the transformation and transaction stages. At this stage, it is not only done with verbal communication (voice) but also mental attitude and personality. At this stage, the communication of personality that plays an 
active role, about how the teruna-daha is given in-depth theory about the procedures for implementing Ngusabha Sambah from krama desa. In addition, to the theory of things that are more important in the trans stage of internalization effectiveness, namely a mentor from each teruna-daha in showing attitudes or behavior in their daily lives which shows that the mentor is a real example as a person of character.

The internalization effectiveness trans process is a process that takes place throughout Ngusabha Sambah in the Tenganan Pegringsingan Traditional Village which is aimed at krama desa and teruna-daha. Throughout this procession, an individual (krama desa and terunadaha) continues to learn to process all feelings, desires, lusts and emotions that make up personality. The first feeling is activated in the personality when starting the initial procession of Ngusabha Sambah. As with krama desa, every individual, both young and old, has an inherent talent to develop various kinds of feelings, desires, passions and emotions in his individual personality, however, the form of activation of various kinds of personality contents is strongly influenced by various kinds of stimuli in their natural surroundings and in their socio-cultural environment.

\section{c. Character Values Found in Ngusabha Sambah \\ Ngusabha Sambah in the process of} internalizing the values of krama desa and teruna-daha in the Tenganan Pegringsingan traditional village, produces moral values that make the individual character. In accordance with what is aspired by the mentors and the Tenganan Pegringsingan community who have a generation of character. In relation to values which are normative benchmarks that influence humans in determining their choices among alternative ways of action. The essence and meaning of values are in the form of norms, ethics, regulations, laws, customs, religious rules and other references that have a price and are felt to be valuable to someone. Values are abstract, are behind the facts, give rise to action, are contained in one's morals, appear as the end of a psychological process and develop in a more complex direction.

Internalization of values obtained by krama desa and teruna-daha that is one of the values of character that is Religious, that is in the application of the results of internalization obtained is the attitude and behavior that is obedient in implementing religious teachings based on culture that has been packaged by their ancestors with an activity which becomes a habit in a tradition. A strong understanding of krama desa and teruna-daha about religious values is the appreciation and implementation of Ngusabha Sambah. Internalization of religious values is a value derived from the belief in God that exists in a person, especially krama desa and terunadaha in the village of Tenganan Pegringsingan. The belief in what has been inherited by the ancestors in the form of ceremonies and traditions, should be maintained together, both in implementation as well as facilities and infrastructure without reducing or exaggerating in the procession to be performed. A deep understanding of Ngusabha Sambah, which is accepted by krama desa and teruna-daha in the process of internalizing values that are specifically about religious values is something that is useful and done by krama desa and terunadaha, in the form of obedient attitude and behavior in carrying out the meaning of Ngusabha Sambah in daily life, about the natural balance of Bhuana Agung and Bhuana Alit.

The process of internalizing social values which is interpreted in Ngusabha Sambah by krama desa and teruna-daha, namely how as an individual should be able to utilize himself to be useful for the lives of other individuals. Social values are often used as a guide for life by the wider community in determining attitudes in daily life, as well as being the value of human life in interacting with other humans. The social 
values obtained by krama desa and terunadaha are not obtained just like that when they were born, but with a value system through the process of internalizing the values taught by their parents, environment, mentors and during periods of formal and informal education.

Understanding the value of tolerance obtained by krama desa and teruna-daha in the process of internalizing character values in the implementation of Ngusabha Sambah about the attitude of krama desa and teruna-daha who are tolerant, live together with energy that is beyond human reason, which is something that is abstract or not real, it is not solely out of fear of abstract things, but rather to maintain harmony in life in Bhuana Agung (the macrocosmic realm) because in this understanding in Ngusabha Sambah, the need for krama desa and teruna-daha understand the position in the sekala world because with the nature human occupies now, it is possible that there will also be inhabitants of the supernatural realm, who have the right to live according to their place.

The procession in the Ngusabha Sambah ceremony provides space for krama desa and teruna-daha to understand a tolerance of living side by side, through this tradition, krama desa and teruna-daha are obliged to respect each other and not disturb the creatures that live in the niskala realm. On the other hand, the inhabitants of the niskala nature want to disturb the comfort of the village community or krama desa and teruna-daha, then they should be allowed to escort or place it in accordance with the place and time owned by the inhabitants of the niskala nature.

The Ngusabha Sambah procession is understood by krama desa and teruna-daha in determining the value of discipline towards the implementation of Ngusabha Sambah which is carried out on time and various facilities and infrastructure are prepared and well planned. This cannot be separated from the importance of selfdiscipline of the importance of preserving a tradition that full of the meaning of character values. Discipline in carrying out formal and informal education in the village, this serves to support the implementation of educational processes and activities as well as religious activities to run smoothly. This is achieved by designing regulations that are firm and not blunt. This has been proven by the traditional village of Tenganan Pegringsingan with the application of awigawig desa which is obeyed by every human being who lives in the village area of Tenganan Pegringsingan. Awig-awig which is applied by krama desa and teruna-daha, moreover for those who also receive informal education related to the meaning of Ngusabha Sambah which has been implemented consistently.

The meaning of Ngusabha Sambah implemented by krama desa and terunadaha shows the growth of friendly and communicative values. This can be seen from the way krama desa and teruna-daha gather and discuss what krama desa and teruna-daha have learned during the implementation of Ngusabha Sambah. With the value of friendly/communicative character, it can be determined by how krama desa and teruna-daha in the association have more friends and of course krama desa and teruna-daha have friendly value because they can communicate better orally and are able to express what they want with friends both among the krama desa and teruna-daha. The implementation of character education obtained by krama desa and teruna-daha is appropriate and in line with the formal education orientation. The learning pattern obtained in the meaning of Ngusabha Sambah is done by instilling moral values in the child that are beneficial for his personal development as an individual and social being. The implementation of learning experiences and learning processes that lead to the formation of character for krama desa and teruna-daha. This process is implemented as a formal education that is through the process of empowerment and cultivating as outlined as one of the principles of national 
education and takes place in three pillars of education, namely the education unit, family and community.

The process of creativity aimed at krama desa and teruna-daha in pouring a sense of art in the facilities of Ngusabha Sambah equipment is inseparable from the ability of krama desa and teruna-daha in processing the sense of art they have, the sense of art is a form of aesthetic value. Aesthetics is one of the areas of knowledge considered important to be studied because there is beauty in the process of creating art through creativity possessed by krama desa and teruna-daha. The creative and aesthetic values acquired by krama desa and terunadaha in the meaning of Ngusabha Sambah provide significant benefits in community life as well as expanding knowledge and perfecting the understanding of the objective elements that evoke a sense of beauty in krama desa and teruna-daha and objective factors which influences the awakening of the beautiful taste, as well as expands the knowledge and perfection of the understanding of the subjective elements that influence the ability to enjoy the beautiful taste.

Creative values in the implementation of krama desa and teruna-daha make facilities and infrastructure related to the implementation of Ngusabha Sambah. This can also strengthen the love for the arts and culture of the Tenganan Pegringsingan traditional village and in general sharpen the ability to appreciate the arts and culture of the nation and deepen the understanding of the relationship between the form of art and the way of life, culture and economy of the community concerned.

The aesthetic value is the result of the creativity of krama desa and teruna-daha in strengthening the ability to assess works of art which indirectly develops art appreciation in society in general with the resulting Ngusabha Sambah process.

Making Ngusabha Sambah facilities requires careful and good planning. Therefore, a person is not only required to be able to make these facilities, but is also required to be able to prioritize the various values that exist in the process of making Ngusabha Sambah infrastructure facilities, as well as bringing some other elements such as aesthetic and philosophical elements. The beautiful Ngusabha Sambah facility not only emphasizes aesthetic value, but has also a moral value how the symbols of this facility are also in accordance with the culture that is developing in society, regarding the use of natural materials. The element of philosophy is usually related to the existence of cultural intervention in an art symbol, thus krama desa and teruna-daha understand the meaning of aesthetic values in implementing the work of facilities and infrastructure in accordance with the elements of beauty without reducing the meaning contained therein.

The meaning of the value of responsibility is implemented by krama desa and teruna-daha in their daily lives, applied in the family environment which is the smallest unit or organization in the community. The beginning of the implementation of the value of responsibility in the family realm, namely in the habit of forming individual personalities which is one of the most important elements in creating safe, peaceful and orderly community conditions. The family is a place. This condition is an ideal condition that will be created when the morals of the community are good and the social welfare of the community is achieved evenly.

The high level of responsibility of every member of the krama desa and teruna-daha in the scope of community life, by carrying out the obligations that krama desa and teruna-daha should perform as members of the community in the scope of youth by carrying out these obligations with full responsibility and high dedication is something that krama desa and terunadaha must do sincerely and selflessly. 


\section{CONCLUSION}

The process of the Ngusabha Sambah ceremony in the Tenganan Pegringsingan Traditional Village, Manggis District, Karangasem Regency is carried out for one month, starting from the Mamiyut ceremony up to Nyajah or the end of the Ngusabha Sambah ceremony, with the culmination of this ceremony being the perang pandan (Makare-kare) which is the symbol of the highest god, namely the god of Indra as the god of war. The process of the occurrence of an effectiveness of internalizing the value of Ngusabha Sambah towards krama desa and terunadaha in the implementation of Ngusabha Sambah. There are three stages that represent the process or stages of the occurrence of the effectiveness of the internalization, namely the value transformation stage, the value transaction stage and the trans stage of internalization effectiveness.

The Ngusabha Sambah procession in the traditional village of Tenganan Pegringsingan, in the process of internalizing character values produces moral values that make the krama desa and teruna-daha have good characteristics. The implementation of Ngusabha Sambah includes religious values, social values, tolerance values, discipline values, friendly/communicative values, creative values, aesthetic values and values of responsibility.

\section{REFERENCES}

Arikunto, S. (2000). Prosedur Penelitian : Suatu Pendekatan Praktis. Yogyakarta : Rineka Cipta.

Awig-awig. (1932).

Koenjraningrat. (2002). Pengantar Antropologi Budaya. Jakarta: Rineka Cipta.

Lukas. (2007). Perkembangan Agama Hindu Dalam Era Globalisasi. Surabaya: Paramita.

Mantra, I. B. ( 1993/1994). Tata Susila Agama Hindu Dharma Denpasar . Parisada Hindu Dharma Pusat.
Moleong, L. (2013). Metedologi Penelitian Kualitatif Edisi Revisi. Bandung: Remaja Rosdakarya.

Penyusun, T. (2003). Undang-Undang Nomor 20 Tahun 2003 Tentang Sistem Pendidikan Nasional. Jakarta: Departemen Pendidikan Nasional Indonesia.

Prastowo, A. (2011). Metode Penelitian Kualitatif dalam Perspektif Rancangan Penelitian. jogjakarta: Ar-ruzz Media.

Ritzer, G. (2003). Sosiologi Ilmu Pengetahuan Berparadigma Ganda. Jakarta: PT. Raja Grafindo Persada.

Rupa. DKK. (2002). Budaya masyarakat Suku Bangsa Bali Aga (Tenganan Pegringsingan). Denpasar.

Ryanto, A. (2004). Metodelogi Penelitian Sosial dan Hukum. Jakarta: Granit.

Sandika, I. K. (2014). Membentuk Siswa Berkarakter Mulia melalui Pola Pembelajaran Pendidikan Agama Hindu. Surabaya: Paramita.

Spradley, J. (2007). Metode Etnografi. Yogyakarta: Tiara Wacana.

Titib, I. M. (2003.). Teologi dan Simbolsimbol Dalam Agama Hindu. Surabaya: Badan Litbang Parisada Hindu Dharma Indonesia Pusat Bekerja Sama dengan Paramitha. 